\title{
HUBUNGAN ANTARA KONSEP DIRI DENGAN KECEMASAN SOSIAL PADA NARAPIDANA PRIA KASUS NARKOTIKA DI LEMBAGA PERMASYARAKATAN KELAS II A PADANG
}

\author{
Rio Andika Putra,Poppy Febri Dina Adli \\ Universitas Putra Indonesia "YPTK" Padang \\ Rioandikaputra@upiyptk.ac.id, poppyfebridinaadli@yahoo.com
}

\begin{abstract}
This study aims to determine the relationship between self-concept and social anxiety in male prisoners of narcotics cases in Padang Class II A Correctional Institution. The independent variables in this study are selfconcept and the dependent variable is social anxiety. The measuring instruments used in this study are selfconcept scale and social anxiety scale. The sampling technique in this study used a simple random sampling technique. The sample in this study were 84 male prisoners of narcotics cases at the Padang Class II A Correctional Institution. Test for validity and reliability in this study using thetechnique Cronbach Alpha. The results of the validity coefficient on the self-concept scale move from $r_{i x}=0.310$ to $r_{i x}=0.779$ with a reliability coefficient of $\alpha=0.944$ while on the social anxiety scale moves from $r_{i x}=0.340$ to $r_{i x}=0.847$ with a reliability coefficient of $\alpha=0.945$. Based on data analysis, the correlation value is -0.567 with a significance level of 0.000 , which means the hypothesis is accepted. This shows that there is a significant relationship between selfconcept and social anxiety in male prisoners of narcotics cases at the Padang Class II A Correctional Institution.
\end{abstract}

Keywords: self-concept, social anxiety and inmates.

\begin{abstract}
ABSTRAK
Penelitian ini bertujuan untuk mengetahui hubungan antara konsep diri dengan kecemasan sosial pada narapidana pria kasus narkotika di Lembaga Permasyarakatan Klas II A Padang. Variabel bebas dalam penelitian ini adalah konsep diri dan variabel terikat adalah kecemasan sosial. Alat ukur yang digunakan dalam penelitian ini adalah skala konsep diri dan skala kecemasan sosial. Teknik pengambilan sampel dalam penelitian ini menggunakan teknik simple random sampling. Sampel dalam penelitian ini adalah 84 orang narapidana pria kasus narkotika di Lembaga Permasyarakatan Klas II A Padang.Uji validitas dan reliabilitas pada penelitian ini menggunakan teknik Alpha Cronbach. Hasil koefisien validitas pada skala konsep diri bergerak dari $\mathrm{r}_{\mathrm{ix}}=0,310$ sampai dengan $r_{i x}=0,779$ dengan koefisien reliabilitas sebesar $\alpha=0,944$ sedangkan pada skala kecemasan sosial bergerak dari $r_{i x}=0,340$ sampai dengan $r_{i x}=0,847$ dengan koefisien reliabilitas sebesar $\alpha=0,945$. Berdasarkan analisis data, diperoleh nilai korelasi sebesar $-0,567$ dengan taraf signifikansi 0,000 yang berarti hipotesis diterima. Hal ini menunjukkan bahwa ada hubungan yang signifikan antara konsep diri dengan kecemasan sosial pada narapidana pria kasus narkotika di Lembaga Permasyarakatan Klas II A Padang.
\end{abstract}

Kata kunci: konsep diri, kecemasan sosial dan narapidana.

\section{PENDAHULUAN}

Dewasa ini di Indonesia tindak kriminal terus meningkat yang membuat pemerintah selalu melakukan formulasi perundang-undangan yang bertujuan untuk membebaskan Indonesia dari maraknya tindak kriminal demi kemajuan, kecerdasan dan kesehatan anak bangsa. Pemerintah pada prinsipnya selalu berusaha sekuat tenaga untuk memberantas tindak kriminal yang terjadi dikalangan masyarakat.

Kehidupan bermasyarakat tidak terlepas dari masalah dan tidak ada penyesuaian yang sempurna karena akan selalu ada penyimpangan dan konflik, hal ini terjadi karena sifat dan keinginan 
manusia yang berbeda-beda. Pada masa sekarang manusia hidup dalam masyarakat yang modern dan sangat kompleks sehingga menumbuhkan aspirasi materil yang tinggi dan mendambakan pemenuhan kebutuhan materil yang melimpah seperti ingin memiliki harta kekayaan dan barang-barang mewah tetapi tidak mempunyai kemampuan untuk mencapainya dengan jalan yang wajar yang disebabkan oleh ketidakmampuan individu beradaptasi dalam menghadapi perubahan sosial yang sangat berdampak negatif bagi kelangsungan hidup.

Masalah tindak kriminal dikalangan masyarakat dapat dikatakan sulit diatasi karena penyelesaiannya melibatkan banyak faktor dan kerjasama dari semua pihak yang bersangkutan, seperti pemerintah, masyarakat, media, keluarga, individu itu sendiri, dan pihak-pihak lain.

Tindak kriminal oleh banyak orang dianggap sebagai suatu kegiatan yang tergolong anti sosial, menyimpang dari moral dan norma-norma di dalam masyarakat serta melanggar aturan-aturan dalam agama (Andriawati dalam Firotussalamah, 2016). Banyak faktor yang dapat mempengaruhi tindak kriminal yaitu faktor demografis seperti pertambahan penduduk, faktor ekologik seperti penyebaran ruang pemukiman, faktor geographic seperti temperature, kelembaban, pertukaran iklim, faktor ekonomi seperti kemiskinan, pengangguran dan faktor sosial seperti ekonomi, keluarga, pendidikan, politik dan agama (Simadjuntak dalam Dermawanti, 2015). Tindak kriminal terdiri dari rentang usia remaja dan dewasa yang berbeda-beda jenis kasus tindak kriminal yang mereka lakukan, salah satunya adalah kasus narkotika.

Secara etimologis narkoba atau narkotika berasal dari bahasa Inggris narcose atau narcosis yang berarti menidurkan dan pembiusan. Narkotika adalah zat alamiah maupun sintetik dari bahan candu atau turunannya dan padanannya yang mempunyai efek psikoaktif atau menurunkan kesadaran (Prisaria, 2012).

\section{Tinjauan Literatur}

\subsection{Kecemasan Sosial}

Kecemasan sosial merupakan gangguan yang terkait dengan sistem biobehavioral positif, termasuk lebih sedikit kejadian kehidupan positif, menghambat emosionalitas positif dan kualitas hidup yang buruk (Kashdan dan Weeks dalam Hofmann \& Dibartolo, 2010). Kecemasan sosial didefinisikan sebagai pengalaman kognitif dan afektif yang dipicu oleh persepsi kemungkinan evaluasi oleh orang lain (Schlenker \& Leary dalam Hofmann \& Dibartolo, 2010).

Menurut Leary (2012) ada tiga aspek dalam kecemasan sosial, yaitu:

a. Ketakutan akan evaluasi negatif

Individu yang mengalami kecemasan sosial akan merasa bahwa dirinya berada dalam posisi rendah sehingga menimbulkan persepsi bahwa orang lain akan meremehkan dirinya atau orang lain tidak akan menyukai dirinya tersebut.

b. Keyakinan yang tidak rasional

Keyakinan yang tidak rasional ditunjukkan dengan persepsi diri terhadap orang lain yang seolah diri menyatakan bahwa orang lain tidak akan menyukainya. Dengan persepsi yang demikian, diri akan cenderung menghindari situasi sosial dimana dirinya merasa akan dipermalukan.

c. Standar yang terlalu tinggi

Keadaan yang ada pada diri individu membuat individu merasa bahwa dirinya tidak dapat memenuhi harapan sosial, yaitu dirinya tidak dapat membuat orang lain terkesan dengan dirinya. Akibatnya ketakutan akan situasi sosialpun akan semakin tinggi.

\subsection{Konsep Diri}

Calhaoun \& Acocella (dalam Ghufron dan Risnawati, 2011) mendefinisikan konsep diri sebagai gambaran mental diri seseorang. Konsep diri adalah penilaian seseorang terhadap dirinya sendiri secara keseluruhan, baik fisik, psikis, sosial maupun moral (Adawiyah, 2012). Konsep diri merupakan gambaran seseorang mengenai diri sendiri yang merupakan gabungan dari keyakinan fisik, psikologis, sosial, emosional aspiratif dan prestasi yang mereka capai (Hurlock dalam Ghufron dan Risnawati, 2011).

Menurut Calhaoun \& Acocella (dalam Ghufron dan Risnawati, 2011) ada tiga aspek dalam konsep diri, yaitu: 
a. Pengetahuan

Pengetahuan adalah apa yang individu ketahui tentang dirinya. Individu di dalam benaknya terdapat suatu daftar yang menggambarkan dirinya, kelengkapan atau kekurangan fisik, usia, jenis kelamin, kebangsaan, suku, pekerjaan, agama dan lain-lain.

b. Harapan

Pandangan tentang kemungkinan dirinya menjadi apa dimasa depan. Individu mempunyai harapan pada dirinya sendiri untuk menjadi diri yang ideal.

c. Penilaian

Individu berkedudukan sebagai penilai tentang dirinya sendiri dimana hasil penilaian tersebut disebut dengan harga diri. Semakin tidak sesuai antara harapan dan standar diri maka akan semakin rendah harga diri seseorang.

\section{METODOLOGI PENELITIAN}

1. Variabel bebas (independent variable) adalah suatu variabel yang variasinya mempengaruhi variabel lain (Azwar, 2014). Variabel bebas dalam penelitian ini adalah konsep diri.

2. Variabel tergantung (dependent variable) adalah variabel penelitian yang diukur untuk mengetahui besarnya efek atau pengaruh variabel lain (Azwar, 2014). Variabel terikat dalam penelitian ini adalah kecemasan sosial.

Populasi adalah wilayah generalisasi yang terdiri dari obyek atau subyek yang mempunyai karakteristik tertentu yang ditetapkan oleh peneliti untuk dipelajari dan kemudian ditarik kesimpulannya (Sugiyono, 2009). Populasi dalam penelitian ini adalah narapidana pria kasus narkotika di Lembaga Permasyarakatan Klas II A Padang yang berjumlah 525 orang.

Sampel adalah sebagian dari jumlah dan karakteristik yang dimiliki oleh populasi tersebut (Sugiyono, 2009). Teknik pengambilan sampel dalam penelitian ini menggunakan teknik simple random sampling dimana peneliti mencampur subjek-subjek di dalam populasi sehingga semua subjek dianggap sama (Arikunto, 2010).

Metode pengumpulan data yang digunakan dalam penelitian ini adalah metode skala. Menurut Azwar (2014) alasan menggunakan metode skala yaitu karena subjek adalah orang yang paling tahu tentang dirinya sendiri. Skala yang digunakan pada skala konsep diri dan skala kecemasan sosial adalah model Likert yang telah dimodifikasi menjadi empat alternatif jawaban dan aitem-aitem dalam skala ini dikelompokkan dalam aitem favourable dan unfavourable.

Analisis data yang digunakan adalah dengan analisis statistik dengan pertimbangan bahwa statistik bekerja dengan angka, bersifat objektif dan universal dalam arti dapat digunakan hampir pada semua bidang penelitian. Menurut Azwar (2014) guna memudahkan dalam melakukan komputasinya, rumusan koefisien korelasi product moment Pearson atau koefisien korelasi Pearson Teknik analisis data menggunakan korelasi product moment dari Pearson yang dilakukan dengan bantuan IBM SPSS 21.0.

\section{HASIL DAN DISKUSI}

Berdasarkan uji validitas dan reliabilitas pada penelitian ini menggunakan teknik product moment dan alpha Cronbach. Diperoleh nilai indeks daya beda aitem skala konsep diri bergerak dari rix = 0,310 sampai dengan rix $=0,779$. Berdasarkan hasil uji coba tersebut, maka dari 42 aitem diperoleh 30 aitem yang valid dan 12 aitem yang gugur sedangkan untuk skala kecemasan sosial diperoleh nilai indeks daya beda aitem bergerak dari rix $=0,340$ sampai dengan rix $=0,847$. Berdasarkan hasil uji coba tersebut, maka dari 42 aitem diperoleh 29 aitem yang valid dan 13 aitem yang gugur. Hasil uji reliabilitas pada penelitian ini menggunakan rumus Alpha Cronbach dengan bantuan program komputer. Koefisien reliabilitas untuk skala job characteristic diperoleh sebesar $\alpha=0,944$ artinya derajat reliabilitas tinggi, maka dapat disimpulkan bahwa butir-butir alat instrumen penelitian tersebut reliabel sedangkan untuk skala kecemasan sosial diperoleh sebesar $\alpha=0,945$ artinya derajat reliabilitas tinggi, maka dapat disimpulkan bahwa butir-butir alat instrumen penelitian tersebut reliabel. 


\subsection{Uji Normalitas}

Tabel 1. Uji Normalitas
\begin{tabular}{|l|c|c|c|c|}
\hline \multicolumn{1}{|c|}{ Variabel } & N & KSZ & P & Sebaran \\
\hline Konsep Diri & 84 & 1,071 & 0,202 & Normal \\
\hline Kecemasan Sosial & 84 & 1,146 & 0,145 & Normal \\
\hline
\end{tabular}

Berdasarkan tabel di atas, maka diperoleh nilai signifikansi pada skala konsep diri sebesar $\mathrm{p}=$ 0,202 dengan $\mathrm{KSZ}=1,071$. Hasil tersebut menunjukkan bahwa nilai $\mathrm{p}>0,05$, artinya sebaran berdistribusi secara normal sedangkan untuk skala kecemasan sosial diperoleh nilai signifikansi sebesar $\mathrm{p}=0,145$ dengan $\mathrm{KSZ}=1,146$, hasil tersebut menunjukkan bahwa nilai $\mathrm{p}$ $>0,05$, artinya sebaran berdistribusi secara normal.

\subsection{Uji Linieritas}

Tabel 2. Uji Linieritas

\begin{tabular}{|c|c|c|c|c|}
\hline $\mathbf{N}$ & Df & Mean Square & F & Sig \\
\hline 84 & 1 & 1626,313 & 46,832 & 0,000 \\
\hline
\end{tabular}

Berdasarkan tabel di atas, maka diperoleh nilai signifikansi sebesar $\mathrm{p}=0,000(\mathrm{p}<0,05)$, artinya varians pada skala konsep dri dan skala kecemasan sosial tergolong linier.

\subsection{Uji Hipotesis}

Tabel 3. Uji Hipotesis

\begin{tabular}{|c|c|c|c|c|c|}
\hline $\mathbf{N}$ & $\mathbf{P}$ & $(\boldsymbol{\alpha})$ & $\mathbf{r}$ & $\mathbf{R ~ S q u a r e}$ & Kesimpulan \\
\hline 84 & 0,000 & 0,01 & $-0,567$ & 0,322 & Hipotesis diterima \\
\hline
\end{tabular}

Berdasarkan uraian tabel di atas, maka diperoleh koefisien korelasi antara variabel konsep diri dengan kecemasan sosial sebesar $r=-0,567$ dengan taraf signifikansi $p=0,000$, maka dapat disimpulkan bahwa ada hubungan antara konsep diri dengan kecemasan sosial pada narapidana pria kasus narkotika di Lembaga Permasyarakatan Klas II A Padang dengan arah hubungan negatif. Hal ini menunjukkan semakin tinggi konsep diri narapidana maka semakin rendah kecemasan sosial dan sebaliknya semakin rendah konsep diri narapidana maka semakin tinggi kecemasan sosial.

Berdasarkan tabel diatas, maka dapat diperoleh gambaran bahwa sebesar 0\% narapidana atau 0 orang narapidana dikategorikan memiliki konsep diri yang rendah dan sebesar $62 \%$ atau 52 orang narapidana dikategorikan konsep diri yang sedang dan sebesar $38 \%$ atau 32 orang narapidana dikategorikan konsep diri yang tinggi sedangkan untuk variabel kecemasan sosial diperoleh gambaran bahwa sebesar $0 \%$ atau 0 orang narapidana memiliki kecemasan sosial yang rendah dan sebesar $25 \%$ atau 21 orang narapidana memiliki kecemasan sosial yang sedang dan sebesar $75 \%$ atau 63 orang narapidana memiliki kecemasan sosial yang tinggi.

Tabel 1. Descriptive Statistic

\begin{tabular}{|l|c|c|c|c|c|}
\hline \multicolumn{1}{|c|}{ Variable } & N & Mean & Std. Deviation & Minimum & Maximum \\
\hline Konsep Diri & 84 & 75 & 15 & 30 & 120 \\
\hline Kecemasan Sosial & 84 & 72,5 & 14,5 & 29 & 116 \\
\hline
\end{tabular}

Berdasarkan hasil penelitian, maka dapat dilakukan pengelompokkan yang mengacu pada kriteria pengkategorisasian dengan tujuan menempatkan individu ke dalam kelompok-kelompok yang terpisah secara berjenjang menurut suatu kontinum berdasarkan atribut yang diukur (Azwar, 2016) sebagai berikut:

Table 2. Norma Kategorisasi

\begin{tabular}{|c|c|}
\hline Norma & Kategorisasi \\
\hline$X<(\mu-1 . \sigma)$ & Rendah \\
\hline$(\mu-1 . \sigma) \leq X<(\mu+1 . \sigma)$ & Sedang \\
\hline
\end{tabular}




\begin{tabular}{|l|l|}
\hline$(\mu+1 . \sigma) \leq \mathrm{X}$ & Tinggi \\
\hline
\end{tabular}

Keterangan:

$\begin{aligned} \mathrm{X} & =\text { skor mentah sampel } \\ \mu & =\text { meau } \\ \sigma & =\text { standar deviasi }\end{aligned}$

Berdasarkan uraian tabel di atas, maka diperoleh kategorisasi subjek penelitian pada konsep diri dan kecemasan sosial sebagai berikut:

Tabel 3. Pengelompokkan Kategorisasi Subjek

\begin{tabular}{|c|c|c|c|c|}
\hline Variabel & Skor & Jumlah & Persentase (\%) & Kategori \\
\hline \multirow{3}{*}{ Konsep Diri } & $30-59$ & 0 & $0 \%$ & Rendah \\
\cline { 2 - 5 } & $60-89$ & 52 & $62 \%$ & Sedang \\
\cline { 2 - 5 } & $90-120$ & 32 & $38 \%$ & Tinggi \\
\hline \multirow{3}{*}{ Kecemasan Sosial } & $29-57$ & 0 & $0 \%$ & Rendah \\
\cline { 2 - 5 } & $58-86$ & 21 & $25 \%$ & Sedang \\
\cline { 2 - 5 } & $87-116$ & 63 & $75 \%$ & Tinggi \\
\hline
\end{tabular}

Berdasarkan tabel diatas, maka dapat diperoleh gambaran bahwa sebesar 0\% narapidana atau 0 orang narapidana dikategorikan memiliki konsep diri yang rendah dan sebesar $62 \%$ atau 52 orang narapidana dikategorikan konsep diri yang sedang dan sebesar $38 \%$ atau 32 orang narapidana dikategorikan konsep diri yang tinggi sedangkan untuk variabel kecemasan sosial diperoleh gambaran bahwa sebesar $0 \%$ atau 0 orang narapidana memiliki kecemasan sosial yang rendah dan sebesar $25 \%$ atau 21 orang narapidana memiliki kecemasan sosial yang sedang dan sebesar $75 \%$ atau 63 orang narapidana memiliki kecemasan sosial yang tinggi.

Adapun sumbangan efektif ( $R$ square) dari variabel konsep diri dan kecemasan sosial dapat ditentukan dengan menggunakan rumus koefisien determinan sebagai berikut:

$$
\begin{aligned}
\mathrm{KP} & =\mathrm{r}^{2} \times 100 \% \\
& =(-0,567)^{2} \times 100 \% \\
& =32,14 \% \\
& =32 \%
\end{aligned}
$$

\section{KESIMPULAN \\ 5.1 KESIMPULAN}

Berdasarkan hasil pengumpulan data dan analisis data yang telah dilakukan oleh peneliti, maka dapat ditarik kesimpulan yang sekaligus merupakan jawaban dari tujuan penelitian adalah sebagai berikut:

1. Berdasarkan analisis uji korelasi menunjukkan bahwa terdapat hubungan antara konsep diri dengan kecemasan sosial dengan arah negatif yang artinya semakin tinggi konsep diri maka semakin rendah kecemasan sosial pada narapidana dan sebaliknya semakin rendah konsep diri maka semakin tinggi kecemasan sosial pada narapidana pria kasus narkotika di Lembaga Permasyarakatan Klas II A Padang, hal ini berarti hipotesis diterima.

2. Adapun sumbangan efektif dari variabel kontrol diri terhadap pembelian impulsif yaitu sebesar $32 \%$.

\section{DAFTAR PUSTAKA}

[1] Adawiyah, Robi'atul. 2012. Hubungan Antara Konsep Diri dan Kecemasan Komunikasi Pada Mahasiswa Psikologi Uin Suka Yogyakarta. Skripsi Program Studi Psikologi Fakultas Ilmu Sosial dan Humaniora Universitas Islam Negeri Sunan Kalijaga Yogyakarta. 
[2] Andriawati, Siti. 2012. Hubungan Konsep Diri Dengan Kecemasan Narapidana Menghadapi Masa Depan di Lembaga Pemasyarakatan Wanita Malang. Skripsi Fakultas Psikologi Universitas Islam Negeri Maulana Malik Ibrahim Malang.

[3] Anggraini, Helen, S. 2015. Hubungan Antara Kepercayaan Diri dan Dukungan Sosial Dengan Kecemasan Sosial Pada Narapidana Anak di Lapas Klas II B Pekanbaru. Skripsi Fakultas Psikologi Universitas Islam Negeri Sultan Syarif Kasim Riau Pekanbaru.

[4] Arikunto, Suharsimi. 2010. Manajemen Penelitian Edisi Revisi. Jakarta: PT Rineka Cipta

[5] Arumsari, Ike, A. 2011. Hubungan Antara Konsep Diri Dengan Komunikasi Antarpribadi Pada Siswa Kelas VIII DI SMP Negeri 2 Jatibarang Brebes Tahun Ajaran 2010/2011. Skripsi Jurusan Bimbingan dan Konseling Fakultas Ilmu Pendidikan Universitas Negeri Semarang

[6] Asrori, Adib. 2015. Terapi Kognitif Perilaku Untuk Mengatasi Gangguan Kecemasan Sosial. Jurnal Nomor ISSN: 2301-8267 Vol. 03, No.01 Januari 2015.

[7] _ Saifuddin. 2016. Reliabilitas dan Validitas Edisi 4. Yogyakarta: Pustaka Pelajar

[8] Badan Narkotika Nasional. 2016. Press Release Akhir Tahun 2016 "Kerja Nyata Perangi Narkotika”. Jakarta: B/PR-90/XII/2016/HUMAS

[9] Dermawanti. 2015. Faktor-Faktor Yang Mempengaruhi Kriminalitas di Kabupaten Batang Tahun 2013 Dengan Analisis Jalur. Jurnal Gaussian, Volume 4, Nomor 2, Tahun 2015, Halaman 247 - 256

[10] Firotussalamah. 2016. Hubungan Konsep Diri Dengan Kecemasan Narapidana Remaja Di LPKA Kelas I Blitar Menjelang Bebas. Skripsi Fakultas Psikologi Universitas Islam Negeri (UIN) Maulana Malik Ibrahim Malang

[11] Ghufron, Nur \& Risnawita, Rini. 2011. Teori-Teori Psikologi. Yogyakarta: Ar-Ruzz Media

[12] Hadi, Sutrisno. 2005. Metodologi Research. Yogyakarta: Andi Offset

[13] Hofmann, Stefan, G \& Dibartolo, Patricia, M. 2010. Social Anxiety: Clinical, Developmental, and Social Perspectives Second Edition. Academic Press Is An Imprint of Elsevier United States of America

[14] Kristanti, Natalia. 2008. Hubungan Antara Konsep Diri Dengan Perilaku Konsumtif Terhadap Pakaian Pada Siswi SMU Stella Duce 2 Yogyakarta. Skripsi Program Studi Psikologi Jurusan Psikologi Fakultas Psikologi Universitas Sanata Dharma Yogyakarta

[15] Leary, Mark. 2012 - The Great Courses Understanding the Mysteries of Human Behavior. United States Of America: The Teaching Company

[16] Misnani, Juniar. 2016. Hubungan Perilaku Asertif dan Kesepian Dengan Kecemasan Sosial Korban Bullying Pada Siswa SMP Negeri 27 Samarinda. Ejournal Psikologi ISSN 2477-2674, ISSN 2477-2666

[17] Mutahari, Hamzah. 2016. Hubungan Antara Kepercayaan Diri Dengan Kecemasan Sosial Pada Siswa Kelas VII SMP Negeri 2 Kalasan Tahun Ajaran 2015-2016. Skripsi Program Studi Bimbingan dan Konseling Jurusan Psikologi Pendidikan dan Bimbingan Fakultas Ilmu Pendidikan Universitas Negeri Yogyakarta

[18] Nugroho, Henricus. Y. A. 2015. Hubungan Konsep Diri dan Kecemasan Narapidana Menjelang Bebas di Lembaga Pemasyarakatan Kelas II A Wirogunan Yogyakarta. Skripsi Fakultas Psikologi Universitas Sanata Dharma Yogyakarta

[19] Prawoto, Yulius, B. 2010. Hubungan Antara Konsep Diri Dengan Kecemasan Sosial Pada Remaja Kelas XI SMA Kristen 2 Surakarta. Skripsi Program Studi Psikologi Fakultas Kedokteran Universitas Sebelas Maret Surakarta

[20] Prisaria, Nusiriska. 2012. Hubungan Pengetahuan dan Lingkungan Sosial Terhadap Tindakan Pencegahan Penyalahgunaan Napza Pada Siswa SMA Negeri 1 Jepara. Skripsi Program Pendidikan Sarjana Kedokteran Fakultas Kedokteran Universitas Diponegoro

[21] Priyatno, Dwi. 2008. Mandiri Belajar SPSS: Bagi Mahasiswa dan Umum. Yogyakarta: MediaKom

[22] Riduwan. 2010. Belajar Mudah Penelitian Untuk Guru, Karyawan dan Peneliti Pemula. Bandung: Alfabeta

[23] Sugiyono. 2009. Metode Penelitian Kuantitati, Kualitatif dan R \& D. Bandung: Penerbit Alfabeta

[24] Suryabrata, Sumadi. 2013. Metodologi Penelitian. Jakarta: PT Raja Grafindo Persada

[25] Tirsae, Okta, V. 2016. Pengaruh Harga Diri Terhadap Kecemasan Sosial Pada Remaja Korban Bullying di Palangkaraya Kalimantan Tengah. Skripsi Program Studi Psikologi Jurusan Psikologi Fakultas Psikologi Universitas Sanata Dharma

[26] Tirtojiwo. 2012. Social Anxiety Disorder (Social Fobia). Malang: Universitas Brawijaya Press (UB Press) 